\title{
SOSIAL EKONOMI DAN INDEKS MASSA TUBUH (IMT) PRIA DEWASA DALAM KAITANNYA DENGAN FAKTOR RISIKO PENYAKIT JANTUNG KORONER DI PERDESAAN DAN PERKOTAAN BOGOR-JAWA BARAT
}

\author{
(Social Economy and Body Mass Index of Men, Its Correlation with Risk Factor of \\ Coronary Heart Disease in Urban and Rural Bogor-West Java)
}

Sri Anna Marliyati ${ }^{1^{*}}$, Megawati Simanjuntak ${ }^{2}$, dan Deni Surya Kencana ${ }^{1}$

1 Departemen Gizi Masyarakat, Fakultas Ekologi Manusia, Institut Pertanian Bogor, Bogor 16680.
2 Departemen Ilmu Keluarga dan Konsumen, Fakultas Ekologi Manusia, Institut Pertanian Bogor,
Bogor 16680.
${ }^{1 *}$ Alamat korespondensi: Departemen Gizi Masyarakat, Fakultas Ekologi Manusia, Institut Pertanian
Bogor, Bogor 16680. Telp: 0251-8621258; Fax: 0251-8622276; Email: anna_marliyati@yahoo.com

\begin{abstract}
The objectives of this research was to study social economy and body mass index of men and it's correlation with risk factor of coronary heart disease in rural and urban of Bogor, West Java. The amount of samples were 100 adult men aged 25-39 of years. Samples were devided into two categories of expense which as < Rp 500.000/capita/month (low income) and $\geq R p 500.000 / \mathrm{cap} /$ month, - (high income). Results of this study showed that using independent $t$-test there was a significant difference between low income and high income samples in rural area in the case of family size, education level, income per capita, total expenditure, nutritional knowledge score and HDL cholesterol level. In urban area, we found significance difference in the case of family size, education level, income per capita, total expenditure, total cholesterol level, LDL and HDL cholesterol level between low income and high income samples. Spearman rank correlation test in rural area showed significance correlation between education level, income per capita, total expenditure, and nutritional knowledge score with HDL cholesterol level. Income per capita and total expenditure correlated significantly with total cholesterol level and BMI correlated significantly with level of triglyceride. Meanwhile, in urban area we found significant correlation between education level, total expenditure, nutritional knowledge score, and $B M I$ with total cholesterol level. Education level and nutritional knowledge score correlated significantly with LDL cholesterol level, and BMI correlated significantly with level of triglyceride.
\end{abstract}

Key Words : Social economy, body mass index, risk factor of coronary heart desease

\section{PENDAHULUAN}

Berbagai penelitian menunjukkan terdapat korelasi positif antara Indeks Massa Tubuh (IMT) dengan lemak tubuh (James et al. 1988 yang diacu dalam Riyadi 2001) dan resiko terkena penyakit degeneratif atau resiko kematian karena penyakit degeneratif (Bray 1990). Oleh karena itu, Indeks Massa Tubuh juga digunakan untuk mengklasifikasikan keadaan gizi lebih pada orang dewasa hubungannya dengan risiko penyakit degeneratif, seperti penyakit jantung koroner.

Penyakit jantung koroner adalah suatu keadaan akibat adanya penyempitan, penyumbatan atau kelainan pembuluh nadi koroner (Krisnatuti \& Yenrina 1999). Penyempitan dan penyumbatan tersebut dikarenakan adanya penimbunan lemak yang lambat dan progresif disebut dengan plak. Plak tersebut akan mengurangi atau memblokir sama sekali aliran darah ke jaringan, sehingga jika otot-otot arteri tertimbun lemak maka elastisitasnya akan menghilang dan kemampuan untuk mengatur tekanan darah akan berkurang (Hull 1996). Dalam kondisi yang lebih parah kemampuan jantung memompa darah dapat hilang sehingga akan merusak pengontrol irama jantung dan berakhir dengan kematian (Krisnatuti \& Yenrina 1999).

Di Indonesia, berdasarkan Survei Kesehatan Rumah Tangga (SKRT) tahun 2001 diperoleh hasil bahwa penyakit sirkulasi (jantung dan pembuluh darah) sebagai penyebab utama kematian yang semakin meningkat jumlahnya dengan peningkatan usia yang dimulai sejak usia 35 tahun ke atas. Sementara itu data di Rumah Sakit Jantung Harapan Kita menunjukkan bahwa penyakit jantung koroner semakin 
banyak mengenai golongan usia muda. Dr. Suhardi MPH menyatakan bahwa dari semua jenis penyakit jantung dan pembuluh darah yang terbanyak di Indonesia adalah penyakit jantung koroner (Sumartono \& Aryastami 1999). Data-data diatas menunjukkan bahwa penyakit jantung koroner merupakan penyakit yang sangat berbahaya dan mematikan.

Bogor sebagai salah satu wilayah yang ditempati selain oleh warga pribumi, juga oleh berbagai jenis suku bangsa yang mempunyai kebudayaan, adat-istiadat, asal daerah, sikap dan perilaku berbeda. Keadaan ini membuka kemungkinan adanya pertemuan dan percampuran berbagai peradaban dan kebudayaan yang akan mempengaruhi tata kehidupan keluarga dan perubahan sosial ekonomi di masyarakat. Untuk mengetahui dampak dari keadaan tersebut terhadap status gizi (IMT) dan risiko terkena penyakit jantung koroner perlu adanya penelitian yang mengkaji keterkaitan antara sosial ekonomi dan Indeks Massa Tubuh (IMT) terhadap risiko penyakit jantung koroner di pedesaan dan perkotaan Bogor, sebagai upaya memperkecil prevalensi penyakit ini.

Secara umum tujuan penelitian ini adalah untuk mengkaji keadaan sosial ekonomi dan Indeks Massa Tubuh (IMT) pria dewasa di perkotaan dan pedesaan Bogor, terutama yang berkaitan dengan risiko penyakit jantung koroner.

\section{METODE}

\section{Desain, Tempat, dan Waktu}

Penelitian ini dilakukan secara cross sectional. Penelitian berlangsung selama 5 bulan, mulai dari bulan Juni hingga Oktober 2005. Tempat penelitian dipilih secara purposif, yaitu kelurahan yang berada di pedesaan dan perkotaan Bogor yang dapat mewakili keberagaman contoh dalam keadaan sosial ekonomi, budaya, pendidikan dan agama. Desa Karehkel di Kecamatan Leuwiliang dan Desa Sinarsari di Kecamatan Dramaga merupakan Desa/kelurahan terpilih yang mewakili contoh di pedesaan, sedangkan daerah Bantar Kemang dan Riau, Kelurahan Baranangsiang Kecamatan Bogor Timur dipilih sebagai kelurahan yang mewakili contoh perkotaan Bogor.

\section{Jumlah dan Cara Penarikan Contoh}

Populasi penelitian adalah pria dewasa yang berumur 25-39 tahun dan tinggal di daerah pedesaan dan perkotaan Bogor. Alasan penentuan contoh pria dewasa berumur 25-39 tahun adalah tingginya angka kematian pada pria usia produktif akibat penyakit jantung koroner. Selain itu pada pria tidak ada efek perlindungan hormon estrogen terhadap penyakit jantung koroner seperti pada wanita. Stratifikasi dilakukan terhadap populasi tersebut, yaitu berdasarkan pendapatan per kapita sebulan sebagai berikut : (1) kelompok dengan pendapatan per kapita sebulan <Rp 500.000 yang selanjutnya disebut kelompok pendapatan rendah, dan (2) kelompok dengan pendapatan per kapita sebulan $\geq$ Rp500.000 yang selanjutnya disebut kelompok pendapatan tinggi. Stratifikasi populasi berdasarkan wilayah penelitian yaitu pedesaan dan perkotaan. Jumlah contoh untuk setiap kelompok pendapatan di pedesaan dan perkotaan adalah 25 orang (total 100 orang) yang dipilih secara purposif dari populasi yang ada di desa/ kelurahan

\section{Teknik Pengambilan Data}

Data sosio-ekonomi dikumpulkan dengan tenik wawancara dengan menggunakan kuesioner, sedangkan data status gizi dikumpulkan dengan cara pengukuran antropometri. Pemeriksaan darah dilakukan dengan cara mengambil sampel darah puasa contoh sebanyak $5 \mathrm{ml}$. Profil darah yang dianalisis adalah kadar kolesterol total, kadar kolesterol HDL, LDL dan trigliserida. Analisis dilakukan menggunakan kits dari Biocon Diagnostica. Pengambilan dan pemeriksaan sampel darah puasa contoh dilakukan dengan bantuan tim medis dari Puslitbang Gizi dan Makanan Bogor. Analisis sampel darah dilakukan di Labora-torium Biokimia Puslitbang Gizi dan Makanan Bogor.

\section{Pengolahan dan Analisis Data}

Data yang dikumpulkan merupakan data kualitatif dan kuantitatif. Data yang telah dikumpulkan kemudian dianalisis secara deskriptif dan inferensia. Data sosial ekonomi contoh digolongkan dalam beberapa kategori, sedangkan data Indeks Massa Tubuh dibandingkan dengan kategori Depkes (1994), yaitu jika subyek IMT nya < 17 maka katego-rinya kurus sekali, 17.00-18.50 kategorinya kurus, 18.5025.00 kategorinya normal, 25.00-27.00 kategorinya gemuk dan > 27 kategorinya gemuk sekali.

Data profil lipid darah yang meliputi kadar kolesterol total, kadar LDL, kadar HDL, dan kadar trigliserida dikelompokkan kedalam kategori normal dan tidak normal setelah 
dibandingkan dengan menggunakan kategori dari AHA (American Heart Association) (2005), yaitu contoh dikatakan normal jika mempunyai kadar kolesterol total $<200 \mathrm{mg} / \mathrm{dl}$, kolesterol $\mathrm{LDL}<100 \mathrm{mg} / \mathrm{dl}$, kolesterol $\mathrm{HDL}>40 \mathrm{mg} / \mathrm{dl}$ dan trigliserida $<150 \mathrm{mg} / \mathrm{dl}$.

Analisis data dilakukan dengan menggunakan Independent Sample T-Test untuk mengetahui perbedaan nilai rata-rata antara kedua kelompok pendapatan di pedesaan dan perkotaan Bogor, serta rata-rata antara pedesaan dan perkotaan Bogor pada kedua keompok pendapatan. Selain itu Uji korelasi Rank Spearman digunakan untuk menganalisis hubungan antara sosial ekonomi dan Indeks Massa Tubuh (IMT) dengan profil lipid darah pria dewasa di pedesaan dan perkotaan Bogor.

\section{HASIL DAN PEMBAHASAN}

\section{Karakteristik Contoh}

Keragaman suku dari hasil penelitian menunjukkan bahwa sebagian besar contoh adalah etnis sunda. Tingkat pendidikan contoh pada kedua wilayah yaitu pedesaan dan perkotaan berbeda. Sebesar 52\% contoh berpendapatan rendah di wilayah pedesaan adalah tamat-SD, sedangkan $56 \%$ contoh berpendapatan tinggi merupakan lulusan sarjana. Contoh berpendapatan rendah di wilayah perkotaan sebesar $44 \%$ merupakan tamatan SMA, sedangkan contoh dengan tingkat pendapatan tinggi sebesar 52\% merupakan tamatan sarjana. Hasil uji beda menunjukkan bahwa tingkat pendidikan contoh berpendapatan rendah berbeda nyata $(p<0.05)$ dengan contoh berpendapatan tinggi, dengan rata-rata lama pendidikan contoh berpendapatan rendah lebih rendah, yaitu $6.2 \pm 1.91$ tahun daripada contoh berpendapatan tinggi yaitu $8.08 \pm 1.44$ tahun. Jadi pendidikan contoh berpendapatan rendah di perkotaan lebih tinggi daripada contoh di pedesaan, sedangkan contoh berpendapatan tinggi, baik di pedesaan maupun di perkotaan tingkat pendidikannya sebagian besar sama, yaitu sarjana. Hasil penelitian ini sesuai dengan pernyataan Martianto dan Ariani (2004) yang menyatakan bahwa tingkat pendidikan formal masyarakat di perkotaan pada umumnya lebih tinggi daripada tingkat pendidikan formal masyarakat di pedesaan.

Berdasarkan hasil penelitian, ternyata pekerjaan contoh bervariasi. Contoh berpendapatan rendah di perkotaan sebagian besar mempunyai pekerjaan lebih baik yaitu sebagai karyawan pabrik (24\%) dibandingkan dengan contoh di pedesaan yang sebagian besar bekerja sebagai buruh (44\%). Hal tersebut berhubungan dengan rendahnyan tingkat pendidikan reponden berpendapatan rendah di pedesaan yang sebagian besar lulusan SD. Contoh berpendapatan tinggi di pedesaan sebesar 52\% mempunyai pekerjaan sebagai pegawai negeri/ABRI, dan di perkotaan pada tingkat pendapatan yang sama sebesar $44 \%$ contoh bekerja sebagai pegawai swasta/BUMN. Hal tersebut dikarenakan contoh di pedesaan secara kebetulan sebagian besar bekerja sebagai dosen di perguruan tinggi negeri.

Jumlah anggota keluarga sebagian besar contoh berpendapatan rendah dan tinggi di pedesaan adalah 4-5 orang, demikian pula contoh berpendapatan rendah di perkotaan sebagian besar mempunya jumlah anggota keluarga 4-5 orang. Akan tetapi jumlah anggota keluarga contoh berpendapatan tinggi di perkotaan sebagian besar $\leq 3$ orang. Hasil uji beda menunjukkan ada perbedaan yang nyata $(p<0.05)$ antara jumlah anggota keluarga contoh berpendapatan rendah dengan jumlah anggota keluarga contoh berpendapatan tinggi di pedesaan. Rata-rata jumlah anggota keluarga contoh berpendapatan rendah $(4.72 \pm$ 2.03) lebih tinggi dibandingkan dengan ratarata jumlah anggota keluarga contoh berpendapatan tinggi $(3.64 \pm 1.52)$. Demikian pula di perkotaan, jumlah anggota keluarga contoh berpendapatan rendah berbeda nyata $(p<0.05)$ dengan contoh berpendapatan tinggi dengan rata-rata jumlah anggota keluarga contoh berpendapatan rendah lebih tinggi (5.44 \pm 2.69) daripada contoh berpendapatan tinggi (3.48 \pm 1.73$)$.

Rata-rata jumlah hari kerja contoh berpendapatan rendah di pedesaan dan perkotaan tidak jauh berbeda yaitu $26 \pm 5.8$ hari kerja di pedesaan dan $26.7 \pm 3$ hari kerja di perkotaan. Sementara rata-rata hari kerja contoh berpendapatan tinggi di perkotaan lebih tinggi daripada contoh di pedesaan.

Hasil uji beda menunjukkan bahwa ratarata pendapatan per kapita contoh berpendapatan rendah di pedesaan berbeda nyata $(p<0.05)$ dengan contoh berpendapatan tinggi. Contoh berpendapatan rendah mempunyai rata-rata pendapatan per kapita per bulan lebih rendah ( $R p 155.857,62 \pm 93.557 .29)$ daripada contoh berpendapatan tinggi (Rp 1.039.480,- \pm 943.316.17). Di perkotaan pun demikian, rata-rata pendapatan per kapita per bulan contoh berpendapatan tinggi lebih tinggi (Rp 1.031.193,- \pm di $513.406,77$ ) daripada 
contoh berpendapatan rendah (Rp 190.079.41 $\pm 113.739,63)$. Rendahnya rata-rata pendapatan per kapita per bulan contoh berpendapatan rendah baik di pedesaan maupun perkotaan dapat dipahami karena terkait dengan jenis pekerjaan. Menurut Hardinsyah dan Suhardjo (1987) besar kecilnya pendapatan yang diterima seseorang dipengaruhi oleh jenis pekerjaan yang dimilikinya, sementara jenis pekerjaan itu sendiri dipengaruhi oleh tingkat pendidikan. Semakin tinggi tingkat pendidikan maka kesempatan untuk mendapatkan pekerjaan semakin besar.

Pengeluaran total contoh berpendapatan rendah baik di pedesaan maupun di perkotaan lebih besar untuk pangan daripada non pangan. Berbeda halnya dengan contoh berpendapatan tinggi, pengeluaran untuk non pangan lebih besar daripada pengeluaran untuk pangan. Hasil penelitian ini memperkuat simpulan yang menyatakan bahwa pada keluarga berpendapatan rendah $60-80 \%$ dari pendapatannya dibelanjakan untuk makanan (Soekirman 1991).

\section{Pengetahuan Gizi}

Tingkat pengetahuan gizi contoh bervariasi menurut kategori wilayah dan pendapatan. Contoh yang bependapatan rendah pada wilayah pedesaan sebagian besar $(92 \%)$ mempunyai skor pengetahuan gizi rendah ( $<60 \%$ skor), hal tersebut disebabkan karena contoh sebagian besar mempunyai tingkat pendidikan yang rendah (Tabel 1). Menurut Sukarni (1989) kemampuan baca tulis (pendidikan) di pedesaan akan membantu dalam memperlancar komunikasi dan penerimaan informasi. Demikian juga pada contoh dengan tingkat pendapatan rendah pada wilayah perkotaan mempunyai pengetahuan gizi rendah ( $<60 \%$ skor) dengan persentase sebesar $52 \%$. Contoh dengan tingkat pendapatan tinggi pada wilayah pedesaan mempunyai pengetahuan gizi baik ( $>80 \%$ skor) dengan persentase $80 \%$, sedangkan $44 \%$ contoh dengan tingkat pendapatan tinggi pada wilayah perkotaan mempunyai pengetahuan gizi sedang $(60-80 \%$ skor).
Hal itu bisa dimengerti karena tingkat pendidikan contoh yang berpendapatan tinggi di pedesaan lebih tinggi daripada contoh berpendapatan tinggi pada wilayah perkotaan, meskipun tidak selalu semakin tinggi pendidikan semakin tinggi pula pengetahuan.

Hasil uji beda menunjukkan bahwa skor pengetahuan gizi contoh berpendapatan rendah di pedesaan berbeda nyata $(p<0.05)$ dengan skor pengetahuan gizi contoh berpendapatan tinggi di wilayah yang sama. Hasil uji beda juga menunjukkan bahwa rata-rata skor pengetahuan gizi contoh berpendapatan rendah di perkotaan berbeda nyata $(p<0.05)$ dengan skor pengetahuan gizi contoh di pedesaan. Demikian juga skor pengetahuan gizi contoh berpendapatan tinggi di pedesaan berbeda nyata dengan skor pengetahuan gizi contoh berpendapatan tinggi di perkotaan.

\section{Status Gizi}

Sebagian besar contoh mempunyai status gizi normal berdasarkan status gizi indeks massa tubuh contoh, baik pada wilayah pedesaan maupun perkotaan pada tingkat pendapatan rendah dan tinggi, dan hanya $8 \%$ contoh dari total contoh mempunyai status gizi kurus sekali (Tabel 2). Persentase contoh dengan status gizi gemuk sekali menempati urutan ke dua terbesar, dimana pada contoh dengan tingkat pendapatan tinggi baik pada wilayah perkotaan maupun pedesaan persentasenya lebih tinggi daripada contoh dengan tingkat pendapatan rendah pada kategori wilayah yang sama. Hal tersebut diduga terjadi karena pola konsumsi contoh berpendapatan tinggi yang gemar mengkonsumsi makanan yang digoreng, makanan dengan kandungan lemak jenuh dan kolesterol yang relatif lebih tinggi dibandingkan contoh berpendapatan rendah.

Hasil uji beda menunjukkan tidak ada ada perbedaan yang nyata $(p>0.05)$ Indeks Massa Tubuh contoh, baik menurut kategori wilayah maupun kategori pendapatan. Indeks massa tubuh (IMT) sebagai salah satu indeks kegemukan, sering digunakan sebagai faktor

Tabel 1. Sebaran Contoh berdasarkan Kategori Pengetahuan Gizi dan Kelompok Pendapatan

\begin{tabular}{|c|c|c|c|c|c|c|c|c|c|}
\hline \multirow{3}{*}{ No } & \multirow{3}{*}{$\begin{array}{c}\text { Kategori pengetahuan } \\
\text { gizi }\end{array}$} & \multicolumn{4}{|c|}{ Pedesaan } & \multicolumn{4}{|c|}{ Perkotaan } \\
\hline & & \multicolumn{2}{|c|}{$\begin{array}{c}\text { Pendapatan } \\
\text { Rendah }(n=25\end{array}$} & \multicolumn{2}{|c|}{$\begin{array}{c}\text { Pendapatan } \\
\text { Tinggi }(n=25)\end{array}$} & \multicolumn{2}{|c|}{$\begin{array}{c}\text { Pendapatan } \\
\text { Rendah }(n=25)\end{array}$} & \multicolumn{2}{|c|}{$\begin{array}{l}\text { Pendapatan } \\
\text { Tinggi }(\mathrm{n}=25)\end{array}$} \\
\hline & & $n$ & $\%$ & $\mathrm{n}$ & $\%$ & $\mathrm{n}$ & $\%$ & $\mathrm{n}$ & $\%$ \\
\hline 1 & Rendah (<60\% skor) & 23 & 92.0 & 0 & 0.0 & 13 & 52.0 & 7 & 28.0 \\
\hline 2 & Sedang $(60-80 \%$ skor $)$ & 2 & 8.0 & 5 & 20.0 & 6 & 24.0 & 11 & 44.0 \\
\hline \multirow[t]{2}{*}{3} & Tinggi (>80\% skor) & 0 & 0.0 & 20 & 80.0 & 6 & 24.0 & 7 & 28.0 \\
\hline & Total & 25 & 100.0 & 25 & 100.0 & 25 & 100.0 & 25 & 100.0 \\
\hline
\end{tabular}


Tabel 2. Sebaran Contoh berdasarkan Kategori Status Gizi IMT

\begin{tabular}{|c|c|c|c|c|c|c|c|c|c|}
\hline \multirow{3}{*}{ No } & \multirow{3}{*}{ Kategori IMT } & \multicolumn{4}{|c|}{ Pedesaan } & \multicolumn{4}{|c|}{ Perkotaan } \\
\hline & & \multicolumn{2}{|c|}{$\begin{array}{c}\text { Pendapatan } \\
\text { Rendah }(n=25)\end{array}$} & \multicolumn{2}{|c|}{$\begin{array}{l}\text { Pendapatan } \\
\text { Tinggi }(n=25)\end{array}$} & \multicolumn{2}{|c|}{$\begin{array}{c}\text { Pendapatan } \\
\text { Rendah }(n=25)\end{array}$} & \multicolumn{2}{|c|}{$\begin{array}{c}\text { Pendapatan } \\
\text { Tinggi }(n=25)\end{array}$} \\
\hline & & $\mathrm{n}$ & $\%$ & $\mathrm{n}$ & $\%$ & $n$ & $\%$ & $\mathrm{n}$ & $\%$ \\
\hline 1 & Kurus Sekali & 0 & 0.0 & 0 & 0.0 & 0 & 0.0 & 2 & 8.0 \\
\hline 2 & Kurus & 3 & 12.0 & 2 & 8.0 & 3 & 12.0 & 0 & 0.0 \\
\hline 3 & Normal & 16 & 64.0 & 11 & 44.0 & 12 & 48.0 & 13 & 52.0 \\
\hline 4 & Gemuk & 0 & 0.0 & 5 & 20.0 & 4 & 16.0 & 2 & 8.0 \\
\hline \multirow[t]{2}{*}{5} & Gemuk Sekali & 6 & 24.0 & 7 & 28.0 & 6 & 24.0 & 8 & 32.0 \\
\hline & Total & 25 & 100.0 & 25 & 100.0 & 25 & 100.0 & 25 & 100.0 \\
\hline
\end{tabular}

pengontrol dalam penelitian hubungan antara ukuran antropometri dengan faktor risiko penyakit kardiovaskuler (Dell et all. 1990 diacu dalam Hiddin 1998).

\section{Profil Lipid Darah}

\section{Kadar Kolesterol Total}

Kadar kolesterol contoh di pedesaan maupun di perkotaan sebagian besar termasuk kategori normal. Contoh dengan kategori kadar kolesterol total tidak normal pada contoh berpendapatan rendah di pedesaan lebih tinggi (24\%) daripada contoh di perkotaan (20\%). Sebaliknya jumlah contoh berpendapatan tinggi di perkotaan dengan kadar kolesterol total tidak normal lebih tinggi (44\%) daripada contoh di pedesaan (32\%) (Tabel 3). Hasil uji beda menunjukkan ada perbedaan yang nyata $(p<0.05)$ antara kadar kolesterol total contoh berpendapatan rendah dengan contoh berpendapatan tinggi di perkotaan, dengan rata-rata kadar kolesterol total contoh berpendapatan tinggi (195.89 \pm 36.22) lebih tinggi daripada rata-rata kadar kolesterol total contoh berpendapatan rendah $(169.68 \pm 29.18)$. Di pedesaan tidak ada perbedaan yang nyata $(p>0.05)$ antara kadar kolesterol total contoh berpendapatan rendah dengan contoh berpendapatan tinggi. Sementara uji beda menurut kategori pendapatan, tidak ada perbedaan yang nyata ( $p>0.05)$ antara kadar kolesterol total contoh berpendapatan tinggi di kedua wilayah.

Tingginya persentase contoh berpendapatan tinggi dengan kadar kolesterol total tidak normal di pedesaan dan di perkotaan terkait dengan status IMT mereka yaitu kategori gemuk sekali. Wiyono et al. (2004) menyatakan setiap peningkatan 1 unit IMT akan meningkatkan $2.49 \mathrm{mg} / \mathrm{dl}$ kolesterol total sementara menurut Kromhout (1983), diacu dalam Wiyono et al (2004) menyatakan bahwa perubahan $1 \mathrm{~kg}$ berat badan akan meningkatkan 2 $\mathrm{mg} / \mathrm{dl}$ kadar kolesterol total.

Sementara tingginya jumlah contoh berpendapatan tinggi dengan kadar kolesterol total tidak normal di perkotaan diduga karena kurangnya kemampuan dalam menerapkan informasi tentang gizi dalam kehidupan seharihari. Selain itu terkait juga dengan tingginya daya beli contoh berpendapatan tinggi yang cenderung banyak mengkonsumsi fast food dan makanan rendah serat. Martianto dan Ariani (2004) menyatakan bahwa variasi makanan dan minuman jadi di kota lebih banyak dan lebih mudah di peroleh baik di pasaran tradisional maupun di supermarket. Menurut Soekirman (1991) pendapatan riil keluarga adalah salah satu faktor yang menentukan konsumsi makanan keluarga. Meningkatnya pendapatan pada perorangan akan terjadi perubahan dalam susunan makanan, akan tetapi pengeluaran yang lebih banyak untuk pangan tidak menjamin lebih beragamnya konsumsi pangan (Soehardjo, 1989).

\section{Kadar HDL}

Hasil penelitian menunjukkan bahwa kadar HDL contoh di pedesaan dan di

Tabel 3. Sebaran Contoh berdasarkan Kategori Kadar Kolesterol Total

\begin{tabular}{|c|c|c|c|c|c|c|c|c|c|}
\hline \multirow{3}{*}{ No } & \multirow{3}{*}{$\begin{array}{l}\text { Kategori } \\
\text { Kolesterol }\end{array}$} & \multicolumn{4}{|c|}{ Pedesaan } & \multicolumn{4}{|c|}{ Perkotaan } \\
\hline & & \multicolumn{2}{|c|}{$\begin{array}{c}\text { Pendapatan } \\
\text { Rendah }(n=25)\end{array}$} & \multicolumn{2}{|c|}{$\begin{array}{c}\text { Pendapatan } \\
\text { Tinggi }(n=25)\end{array}$} & \multicolumn{2}{|c|}{$\begin{array}{c}\text { Pendapatan } \\
\text { Rendah }(n=25)\end{array}$} & \multicolumn{2}{|c|}{$\begin{array}{c}\text { Pendapatan } \\
\text { Tinggi }(n=25)\end{array}$} \\
\hline & & $n$ & $\%$ & $\mathrm{n}$ & $\%$ & $\mathrm{n}$ & $\%$ & $\mathrm{n}$ & $\%$ \\
\hline 1 & Tidak Normal & 6 & 24.0 & 8 & 32.0 & 5 & 20.0 & 11 & 44.0 \\
\hline \multirow[t]{2}{*}{2} & Normal & 19 & 76.0 & 17 & 68.0 & 20 & 80.0 & 14 & 56.0 \\
\hline & Total & 25 & 100.0 & 25 & 100.0 & 25 & 100.0 & 25 & 100.0 \\
\hline
\end{tabular}


Tabel 4. Sebaran Contoh berdasarkan Kategori Kadar Kolesterol HDL

\begin{tabular}{|c|c|c|c|c|c|c|c|c|c|}
\hline \multirow{3}{*}{ No } & \multirow{3}{*}{$\begin{array}{c}\text { Kategori } \\
\text { Kadar kolesterol } \\
\text { HDL }\end{array}$} & \multicolumn{4}{|c|}{ Pedesaan } & \multicolumn{4}{|c|}{ Perkotaan } \\
\hline & & \multicolumn{2}{|c|}{$\begin{array}{c}\text { Pendapatan } \\
\text { Rendah }(n=25)\end{array}$} & \multicolumn{2}{|c|}{$\begin{array}{c}\text { Pendapatan } \\
\text { Tinggi }(n=25)\end{array}$} & \multicolumn{2}{|c|}{$\begin{array}{c}\text { Pendapatan } \\
\text { Rendah }(n=25)\end{array}$} & \multicolumn{2}{|c|}{$\begin{array}{c}\text { Pendapatan } \\
\text { Tinggi }(n=25)\end{array}$} \\
\hline & & $\mathrm{n}$ & $\%$ & $\mathrm{n}$ & $\%$ & $\mathrm{n}$ & $\%$ & $\mathrm{n}$ & $\%$ \\
\hline 1 & Tidak Normal & 10 & 40.0 & 2 & 8.0 & 11 & 44.0 & 7 & 28.0 \\
\hline \multirow[t]{2}{*}{2} & Normal & 15 & 60.0 & 23 & 92.0 & 14 & 56.0 & 18 & 72.0 \\
\hline & Total & 25 & 100.0 & 25 & 100.0 & 25 & 100.0 & 25 & 100.0 \\
\hline
\end{tabular}

perkotaan pada kedua kelompok pendapatan sebagian besar termasuk kategori normal. Akan tetapi kategori kadar HDL tidak normal pada contoh berpendapatan rendah relatif tinggi di pedesaan (40\%) dan di perkotaan (44\%) (Tabel 4). Hasil uji beda menunjukkan bahwa kadar HDL contoh berpendapatan rendah di pedesaan berbeda nyata $(p<0.05)$ dengan kadar HDL contoh yang berpendapatan tinggi. Rata-rata kadar HDL contoh berpendapatan tinggi lebih besar yaitu $49.32 \pm 8.33$ daripada rata-rata kadar HDL contoh berpendapatan rendah yaitu $40.57 \pm 6.91$. Demikian halnya di perkotaan ada perbedaan yang nyata antara contoh berpendapatan rendah dengan contoh berpendapatan tinggi. Rata-rata kadar HDL contoh berpendapatan tinggi yaitu $43.52 \pm$ 6.22 lebih tinggi daripada contoh berpendapatan rendah yaitu $40.08 \pm 4.09$. Hasil uji beda menurut kategori pendapatan menunjukkan ada perbedaan yang nyata $(p<0.05)$ antara kadar HDL contoh berpendapatan tinggi di pedesaan dan di perkotaan, dengan rata-rata kadar HDL darah contoh di pedesaan lebih tinggi yaitu $49.32 \pm 8.38$ daripada rata-rata kadar HDL contoh di perkotaan yaitu $43.54 \pm$ 6.22. Sementara itu tidak ada perbedaan yang nyata $(p>0.05)$ antara contoh berpendapatan rendah di pedesaan dan di perkotaan.

Tingginya jumlah contoh berpendapatan rendah yang mempunyai kadar kolesterol HDL tidak normal mungkin diakibatkan oleh rendahnya tingkat pendidikan dan pengetahuan gizi yang dimiliki contoh sehingga akan berdampak pada pola konsumsi pangan yang tidak sehat, dan faktor lain yang tidak dapat menurunkan kadar HDL seperti merokok, obesitas, tingkat aktifitas fisik rendah, hipertrigliseridemia dan faktor genetis.

HDL merupakan salah satu jenis kolesterol yang bersifat negatif/menghambat kejadian penyakit jantung koroner. Hal tersebut karena HDL berperan melindungi jantung terkait peranannya mengangkut kolesterol dari jaringan ke hati, untuk selanjutnya dikeluarkan di usus halus (Yuniarti, 2000). Selain itu HDL juga berperan sebagai antioksidan yang dapat mencegah teroksidasinya LDL (Wiyono et al., 2004). Penurunan a mg/dl HDL akan meningkatkan kemungkinan penyakit jantung koroner 2-2\% (Yuniarti 2000). Lebih lanjut Gunawan (2005) menyatakan bahwa resiko kematian karena penyakit jantung koroner empat kali lipat bila kolesterol HDL $<35 \mathrm{mg} / \mathrm{dl}$.

\section{Kadar Kolesterol LDL}

Hasil penelitian menunjukkan bahwa contoh berpendapatan rendah di pedesaan sebagian besar (68\%) mempunyai kadar kolesterol LDL normal, sementara contoh yang berpendapatan tinggi lebih banyak yang tidak normalnya (52\%) daripada yang normal. Berbeda halnya dengan contoh di perkotaan baik yang berpendapatan rendah maupun yang berpendapatan tinggi sebagian besar mempunyai kategori kadar kolesterol LDL tidak normal dengan persentase berturut-turut $52 \%$ pada contoh berpendapatan rendah dan $88 \%$ pada contoh berpendapatan tinggi. Hasil uji beda menyatakan bahwa ada perbedaan yang nyata $(p<0.05)$ antara contoh berpendapatan rendah di perkotaan dengan contoh berpendapatan tinggi dengan rata-rata kadar kolesterol LDL contoh berpendapatan tinggi lebih tinggi yaitu $129.48 \pm 32.75$ daripada contoh berpendapatan rendah yaitu $105.40 \pm 27.09$, sedangkan di pedesaan tidak ada perbedaan yang nyata $(p>0.05)$ antara contoh berpendapatan rendah dengan contoh berpendapatan tinggi. Uji beda menurut kategori pendapatan, ada perbedaan yang nyata $(p<0.05)$ antara contoh berpendapatan tinggi di kedua wilayah, dengan ratarata kadar LDL contoh di perkotaan lebih tinggi yaitu $129.48 \pm 32.75$ daripada contoh di pedesaan yaitu $107.77 \pm 28.06$. Sementara itu tidak ada perbedaan yang nyata $(p>0.05)$ antara contoh berpendapatan rendah di kedua wilayah.

Berat badan sebagai salah satu komponen/variabel penentuan IMT mempunyai hubungan dengan kadar kolesterol LDL. Penurunan berat badan akan menurunkan kadar kolesterol LDL (Kromhout 1983, diacu dalam Wiyono et al 2004). Tingginya persentase kadar kolesterol LDL tidak normal pada contoh berpendapatan tinggi di perkotaan dan di 
pedesaan serta contoh berpendapatan rendah di perkotaan (Tabel 5) diduga disebabkan status indeks massa tubuh mereka yang sebagian besar gemuk dan gemuk sekali. Menurut Yuniarti (2000) kelebihan berat badan mempunyai hubungan dengan kadar lipid dalam darah. Lebih lanjut Wiyono et al (2004) menyatakan bahwa ada hubungan antara indeks massa tubuh dengan kolesterol LDL. Setiap peningkatan 1 unit IMT akan meningkatkan 1.65 $\mathrm{mg} / \mathrm{dl}$ kolesterol LDL. Karena LDL kolesterol menyebabkan pengapuran, pengiriman dan penimbunan pada pembuluh koroner maka kolesterol LDL dianggap sebagai faktor resiko utama penyakit jantung koroner. Kejadian penyakit jantung koroner meningkat 1\% untuk setiap peningkatan $1 \mathrm{mg} / \mathrm{dl}$ kolesterol LDL (Wiyono et al. 2004).

\section{Kadar Trigliserida}

Tabel 6 menunjukkan bahwa kadar trigliserida contoh sebagian besar termausk dalam kategori normal, kecuali pada contoh berpendapatan rendah di pedesaan sebagian besar (64\%) mempunyai kategori kadar trigliserida tidak normal. Hasil uji beda mendapatkan bahwa ada perbedaan yang nyata $\mathrm{p}<0.05$ antara contoh berpendapatan rendah di pedesaan dan contoh di perkotaan dengan rata-rata kadar trigliserida contoh di pedesaan lebih tinggi yaitu $189.00 \pm 92.47$ dibandingkan dengan rata-rata kadar trigli-serida contoh di perkotaan yaitu sebesar $121.39 \pm 65.82$, sedangkan pada contoh berpendapatan tinggi di kedua wilayah tidak ada perbedaan yang nyata $(p>0.05)$. Sementara hasil uji beda menurut kategori wilayah menunjukkan tidak ada perbedaan yang nyata $(p>0.05)$ kadar trigliserida contoh baik di pedesaan maupun di perkotaan pada kedua kelompok pendapatan.

Tingginya kadar trigliserida yang tidak normal pada contoh berpendapatan rendah di pedesaan diduga karena pengaruh pola konsumsi contoh yang sebagian besar menyukai makanan yang digoreng. Selain itu rata-rata skor pada konsumsi karbohidratnya tinggi (Puspitasari, 2006). Almatsier (2004) menyatakan bahwa kadar trigliserida dalam tubuh diperoleh dari lemak makanan dan perubahan unsur-unsur energi yang berlebihan (konsumsi karbohidrat sederhana yang berlebihan). Trigliserida merupakan salah satu faktor resiko penyakit jantung koroner, meskipun mekanisme pada proses terjadinya aterogenik belum begitu pasti. Beberapa hasil penelitian PROCAM (Prospective Cardiovascular Munster Study) menunjukkan bahwa kadar trigliserida yang tinggi dan rasio LDL/HDL tinggi > 5 dapat menjadi faktor resiko yang kuat terjadinya resiko penyakit jantung koroner (Alwi 1996).

\section{Rasio Kolesterol Total terhadap HDL}

Hasil penelitian mendapatkan bahwa sebagian besar contoh baik di pedesaan maupun di perkotaan pada kedua kelompok pendapatan memiliki rasio kolesterol total terhadap HDL > 3.5:1, dengan persentase terbesar yaitu pada contoh berpendapatan tinggi di perkotaan (Tabel 7). Hal tersebut menunjukkan bahwa contoh berpendapatan tinggi di perkotaan memiliki peluang yang lebih tinggi untuk terkena penyakit jantung koroner. Tingginya jumlah contoh berpendapatan tinggi di perkotaan dengan rasio

Tabel 5. Sebaran Contoh berdasarkan Kategori Kadar LDL

\begin{tabular}{|c|c|c|c|c|c|c|c|c|c|}
\hline \multirow{3}{*}{ No } & \multirow{3}{*}{ Kategori Kadar LDL } & \multicolumn{4}{|c|}{ Pedesaan } & \multicolumn{4}{|c|}{ Perkotaan } \\
\hline & & \multicolumn{2}{|c|}{$\begin{array}{c}\text { Pendapatan } \\
\text { Rendah }(n=25)\end{array}$} & \multicolumn{2}{|c|}{$\begin{array}{c}\text { Pendapatan } \\
\text { Tinggi }(n=25)\end{array}$} & \multicolumn{2}{|c|}{$\begin{array}{c}\text { Pendapatan } \\
\text { Rendah }(n=25)\end{array}$} & \multicolumn{2}{|c|}{$\begin{array}{c}\text { Pendapatan } \\
\text { Tinggi }(n=25)\end{array}$} \\
\hline & & $\mathrm{n}$ & $\%$ & $\mathrm{n}$ & $\%$ & $\mathbf{n}$ & $\%$ & $\mathrm{n}$ & $\%$ \\
\hline 1 & Tidak Normal & 8 & 32.0 & 13 & 52.0 & 13 & 52.0 & 22 & 88.0 \\
\hline 2 & Normal & 17 & 68.0 & 12 & 48.0 & 12 & 48.0 & 3 & 12.0 \\
\hline & Total & 25 & 100.0 & 25 & 100.0 & 25 & 100.0 & 25 & 100.0 \\
\hline
\end{tabular}

Tabel 6. Sebaran Contoh berdasarkan Kategori Kadar Trigliserida

\begin{tabular}{|c|c|c|c|c|c|c|c|c|c|}
\hline \multirow{3}{*}{ No } & \multirow{3}{*}{$\begin{array}{c}\text { Kategori Kadar } \\
\text { Trigliserida }\end{array}$} & \multicolumn{4}{|c|}{ Pedesaan } & \multicolumn{4}{|c|}{ Perkotaan } \\
\hline & & \multicolumn{2}{|c|}{$\begin{array}{c}\text { Pendapatan } \\
\text { Rendah }(n=25)\end{array}$} & \multicolumn{2}{|c|}{$\begin{array}{c}\text { Pendapatan } \\
\text { Tinggi }(n=25)\end{array}$} & \multicolumn{2}{|c|}{$\begin{array}{c}\text { Pendapatan } \\
\text { Rendah }(n=25)\end{array}$} & \multicolumn{2}{|c|}{$\begin{array}{c}\text { Pendapatan } \\
\text { Tinggi }(n=25)\end{array}$} \\
\hline & & $n$ & $\%$ & $\mathrm{n}$ & $\%$ & $n$ & $\%$ & $\mathrm{n}$ & $\%$ \\
\hline 1 & Tidak Normal & 16 & 64.0 & 11 & 44.0 & 6 & 24.0 & 5 & 20.0 \\
\hline \multirow[t]{2}{*}{2} & Normal & 9 & 36.0 & 14 & 56.0 & 19 & 76.0 & 20 & 80.0 \\
\hline & Total & 25 & 100.0 & 25 & 100.0 & 25 & 100.0 & 25 & 100.0 \\
\hline
\end{tabular}


Tabel 7. Sebaran Contoh berdasarkan Rasio Kolesterol Total Terhadap HDL

\begin{tabular}{|c|c|c|c|c|c|c|c|c|c|}
\hline \multirow{3}{*}{ No } & \multirow{3}{*}{$\begin{array}{c}\text { Rasio Kolesterol Total } \\
\text { terhadap HDL }\end{array}$} & \multicolumn{4}{|c|}{ Pedesaan } & \multicolumn{4}{|c|}{ Perkotaan } \\
\hline & & \multicolumn{2}{|c|}{$\begin{array}{c}\text { Pendapatan } \\
\text { Rendah }(n=25) \\
\end{array}$} & \multicolumn{2}{|c|}{$\begin{array}{l}\text { Pendapatan } \\
\text { Tinggi }(n=25)\end{array}$} & \multicolumn{2}{|c|}{$\begin{array}{c}\text { Pendapatan } \\
\text { Rendah }(n=25)\end{array}$} & \multicolumn{2}{|c|}{$\begin{array}{l}\text { Pendapatan } \\
\text { Tinggi }(n=25)\end{array}$} \\
\hline & & $\mathrm{n}$ & $\%$ & $\mathrm{n}$ & $\%$ & $\mathrm{n}$ & $\%$ & $\mathrm{n}$ & $\%$ \\
\hline 1 & $>3.5: 1$ & 19 & 76.0 & 16 & 64.0 & 20 & 80.0 & 21 & 84.0 \\
\hline 2 & $\leq 3.5: 1$ & 6 & 24.0 & 9 & 36.0 & 5 & 20.0 & 4 & 16.0 \\
\hline & Total & 25 & 100.0 & 25 & 100.0 & 25 & 100.0 & 25 & 100.0 \\
\hline
\end{tabular}

kolesterol total/HDL > 3.5:1, diduga terkait dengan indeks massa tubuh gemuk sekali. Indeks massa tubuh mempunyai hubungan dengan kadar kolesterol total. Seperti yang diungkapkan Kromhout (1983), diacu dalam Wiyono et al (2004) setiap peningkatan 1 unit IMT akan meningkatkan $2.49 \mathrm{mg} / \mathrm{dl}$ kolesterol total. Selain itu tingginya tingkat pendapatan pada kelompok ini juga diduga berpengaruh terhadap pola makan yang tinggi lemak, tinggi protein, rendah karbohidrat dan rendah serat.

Kolesterol total merupakan ukuran yang paling banyak digunakan untuk menggambarkan kolesterol darah. Beberapa ahli menggunakan rasio kolesterol total/HDL untuk mengetahui resiko penyakit jantung koroner. Rasio kolesterol total terhadap/HDL yang direkomendasikan oleh AHA (American Heart Association) adalah $\leq 3.5: 1$. Kadar HDL yang rendah dan kadar kolesterol darah yang tinggi akan meningkatkan resiko penyakit jantung koroner (AHA 2005).

\section{Hubungan antara Keadaan Sosial Ekonomi dan Indeks Massa Tubuh (IMT) dengan Profil Lipid Darah}

\section{Contoh di Pedesaan}

Berdasarkan uji korelasi Rank Spearman menunjukkan jumlah anggota keluarga berhuhubungan negatif tidak nyata dengan kadar kolesterol total, kolesterol LDL dan kolesterol HDL serta berhubungan positif tidak nyata dengan kadar trigliserida. Hal ini berarti dengan meningkatnya jumlah anggota keluarga tidak diikuti dengan penurunan ketiga jenis kolesterol tersebut dan peningkatan jumlah anggota keluarga tidak meningkatkan kadar trigliserida.

Pendidikan contoh $(\mathrm{p}<0.05)$, pendapatan per kapita $(p<0.05)$, pengeluaran total $(p<0.05)$ dan skor pengetahuan gizi $(p<0.05)$ berhubungan positif nyata dengan kadar kolesterol HDL. Hal ini menunjukkan dengan meningkatnya pendidikan, pendapatan per kapita, pengeluaran total dan skor pengetahuan gizi contoh akan meningkatkan kadar kolesterol HDL. Pendidikan secara tidak lang- sung melalui jenis pekerjaan berpengaruh terhadap tingkat pendapatan individu (Hardinsyah \& Suhardjo 1987). Pendapatan akan mempengaruhi terhadap daya beli penyediaan pangan yang berkualitas, sehingga secara tidak langsung pendapatan berpengaruh terhadap kebiasaan makan (Suhardjo 1989). Sementara tingkat pendidikan akan berpengaruh terhadap pengetahuan gizi dan kesehatan individu, sehingga akan berpengaruh juga terhadap pola konsumsi pangan. Semakin banyak pengetahuan tentang gizi dan kesehatan, maka semakin beragam pula jenis makanan yang dikonsumsi sehingga dapat memenuhi kecukupan gizi dan mempertahankan kesehatan individu (Suhardjo 1989).

Pendapatan per kapita $(\mathrm{p}<0.05)$ dan pengeluaran total $(p<0.05)$ berhubungan positif nyata dengan kadar kolesterol total dan pendapatan per kapita $(p<0.05)$, pengeluaran total $(p<0.05)$ dengan kadar kolesterol LDL. Hal ini menunjukkan bahwa dengan meningkatnya pendapatan per kapita dan pengeluaran total contoh akan meningkatkan kadar kolesterol total dan kadar kolesterol LDL.

Salah satu sumber kolesterol dalam tubuh berasal dari makanan yang dikonsumsi, sementara kualitas dan kuantitas makanan yang dikonsumsi tergantung pada kemampuan daya beli. Berg (1986) menyatakan meningkatnya pendapatan pada perorangan akan terjadi perubahan dalam susunan makanan. Akan tetapi pengeluaran yang lebih banyak untuk pangan tidak menjamin lebih beragamnya konsumsi pangan. Kelompok yang berpendapatan tinggi memiliki kebiasaan makan makanan yang melebihi kebutuhannya. Makin tinggi tingkat sosial ekonomi seseorang biasanya berkorelasi dengan makin tingginya konsumsi makanan tinggi lemak, protein dan gula (Suhardjo \& Riyadi 1990). Sementara Sulastri et al (2005) menyatakan individu dengan sosio ekonomi rendah akan cenderung memilih makanan yang tidak sehat seperti asupan tinggi lemak total, asam lemak jenuh, gula, rendah serat dan antioksidan. 
Indeks massa tubuh contoh hanya berkorelasi positif nyata $(p<0.05)$ dengan kadar trigliserida. Hal ini berarti bahwa dengan meningkatnya indeks massa tubuh akan meningkatkan kadar trigliserida. Menurut Almatsier (2004) salah satu yang dapat meningkatkan kadar trigliserida adalah kegemukan. Sementara indeks massa tubuh merupakan salah satu indeks kegemukan. Berbagai penelitian menunjukkan bahwa terdapat korelasi positif antara indeks massa tubuh (IMT) dengan lemak tubuh (James et al 1988 diacu dalam Riyadi 2001).

\section{Contoh di Perkotaan}

Hubungan antara sosial ekonomi dan indeks massa tubuh di perkotaan, berdasarkan hasil uji korelasi Rank Spearman menunjukkan bahwa jumlah anggota keluarga dan pendapatan per kapita berhubungan negatif tidak nyata dengan profil lipid darah. Hal ini menunjukkan bahwa meningkatnya jumlah anggota dan pendapatan per kapita tidak diikuti dengan penurunan kadar lipid darah contoh.

Pendidikan contoh $(p<0.05)$, pengeluaran total $(p<0.05)$, skor pengetahuan gizi $(p<0.05)$ dan indeks massa tubuh $(p<0.05)$ berhubungan nyata positif dengan kadar kolesterol total. Hal ini berarti dengan meningkatnya pendidikan, pengeluaran total, skor pengetahuan gizi dan indeks massa tubuh contoh akan meningkatkan kadar kolesterol total contoh di perkotaan. Hasil penelitian Wiyono et al (2004) mendapatkan bahwa ada hubungan antara indeks massa tubuh dengan kolesterol total. Setiap peningkatan 1 unit IMT akan meningkatkan $2.49 \mathrm{mg} / \mathrm{dl}$ kolesterol total.

Pendidikan contoh $(p<0.05)$ dan skor pengetahuan gizi contoh $(p<0.05)$ berhubungan positif nyata dengan kadar kolesterol LDL. Hal ini berarti bahwa meningkatnya pendidikan dan skor pengetahuan gizi contoh akan meningkatkan kadar kolesterol LDL. Selain makanan, faktor lain yang berpengaruh pada peningkatan kolesterol adalah keturunan, banyaknya merokok, ketegangan batin, dan lain sebagainya (Kertohoesodo 1987). Selain dengan kadar kolesterol total, IMT juga berkolerasi positif nyata dengan kadar trigliserida. Hal ini menunjukkan bahwa meningkatnya IMT maka akan meningkatkan kadar trigliserida. Menurut Almatsier (2004) trigliserida dalam tubuh dapat diperoleh dari lemak makanan atau dari hasil perubahan unsurunsur energi yang berlebihan (konsumsi karbohidrat sederhana yang berlebihan), selain faktor makanan, faktor lain yang dapat meningkatkan kadar trigliserida dalam tubuh yaitu kegemukan.

\section{KESIMPULAN}

Contoh sebagian besar bersuku Sunda, dan Jawa merupakan suku kedua terbesar. Jumlah anggota keluarga contoh baik di pedesaan maupun di perkotaan sebagian besar mempunyai jumlah anggota keluarga 4-5 orang. Tingkat pendidikan contoh berpendapatan tinggi baik di pedesaan maupun di perkotaan sebagian besar adalah sarjana, sedangkan tingkat pendidikan contoh berpendapatan rendah di perkotaan sebagian besar tamat SMA dan di pedesaan sebagian besar tamat SD. Pengetahuan gizi contoh berpendapatan rendah baik di pedesaan maupun di perkotaan sebagian besar mempunyai pengetahuan gizi rendah, sedangkan contoh berpendapatan tinggi di pedesaan sebagian besar berkategori baik dan di perkotaan berkategori sedang.

Contoh berpendapatan rendah seba-gian besar bekerja sebagai buruh di pedesaan dan karyawan pabrik di perkotaan, sedangkan contoh berpendapatan tinggi di pedesaan sebagian besar bekerja sebagai pegawai negeri/ABRI dan di perkotaan bekerja sebagai pegawai swasta/BUMN. Rata-rata jumlah hari kerja kerja contoh berpendapatan rendah di pedesaan dan di perkotaan adalah 30 hari, sedangkan contoh berpendapatan tinggi di perkotaan bekerja selama 26 hari dan di pedesaan bekerja selama 20 hari. Pendapatan per kapita contoh berpendapatan rendah di perkotaan lebih besar (Rp 190.079,4) daripada di pedesaan (Rp 155.857,6), sedangkan pendapatan per kapita contoh berpendapatan tinggi di pedesaan lebih tinggi ( $\operatorname{Rp~1.039.480.0)~daripada~di~per-~}$ kotaan (Rp 1.031.193,3). Pengeluaran total contoh berpendapatan rendah baik di pedesaan maupun di perkotaan lebih besar untuk pangan daripada non pangan.

Indeks massa tubuh IMT contoh sebagian besar normal baik di pedesaan maupun di perkotaan dan hanya $8 \%$ contoh dengan status IMT kurus sekali. Persentase IMT gemuk sekali cenderung tinggi pada contoh berpendapatan tinggi sebesar $28 \%$ di pedesaan dan $32 \%$ di perkotaan, sehingga contoh berpendapatan tinggi di perkotaan mempunyai peluang untuk terjadinya resiko penyakit jantung koroner.

Kategori kadar kolesterol total, kolesterol HDL, dan trigliserida di pedesaan dan di perkotaan sebagian besar termasuk kategori normal. Kecenderungan kadar kolesterol total 
tidak normal pada contoh berpendapatan tinggi di perkotaan lebih tinggi daripada di pedesaan. Kadar kolesterol HDL tidak normal pada contoh berpendapatan rendah relatif tinggi di pedesaan dan di perkotaan. Kadar trigliserida tidak normal paling tinggi pada contoh berpendapatan rendah di pedesaan, dan kategori kadar kolesterol LDL sebagian besar tidak normal pada contoh berpendapatan tinggi dan rendah di perkotaan serta contoh berpendapatan tinggi di pedesaan.

Rata-rata tertinggi kadar kolesterol total dan kadar kolesterol LDL pada contoh berpendapatan tinggi di perkotaan. Rata-rata kadar kolesterol HDL tertinggi pada contoh berpendapatan tinggi di pedesaan dan ratarata tertinggi kadar trigliserida pada contoh berpendapatan rendah di pedesaan. Rasio kadar kolesterol total terhadap HDL tidak normal tertinggi pada contoh berpendapatan tinggi di perkotaan mempunyai peluang yang lebih tinggi terkena penyakit jantung koroner.

Hasil uji beda menunjukkan ada perbedaan yang nyata $(p<0.05)$ antara contoh berpendapatan rendah dan contoh berpendapatan tinggi di pedesaan dalam hal jumlah anggota keluarga, tingkat pendidikan, pendapatan per kapita, pengeluaran total, skor pengetahuan gizi dan kadar kolesterol HDL. Di perkotaan terdapat perbedaan yang nyata $(p<0.05)$ dalam hal jumlah anggota keluarga, pendidikan contoh, pendapatan per kapita, pengeluaran total, kadar kolesterol total, kadar kolesterol LDL dan kadar kolesterol HDL, antara contoh berpendapatan rendah dengan contoh berpendapatan tinggi.

Uji korelasi Rank Spearman di pedesaan menunjukkan terdapat hubungan nyata antara pendidikan contoh $(r=0.569)(p<0.05)$, pendapatan per kapita $(r=0.298)(p<0.05)$, pengeluaran total $(r=0.488)(p<0.05)$, dan skor pengetahuan gizi $(r=0.536) \quad(p<0.05)$ dengan kadar kolesterol HDL. Pendapatan per kapita $(r=$ $0.298)(p<0.05)$, pengeluaran total $(r=0.319)$ $(p<0.05)$ berhubungan nyata dengan kadar kolesterol total dan IMT berhubungan nyata $(r=0.335) \quad(p<0.05)$ dengan kadar trigliserida. Sementara di perkotaan menunjukkan ada hubungan yang nyata antara pendidikan contoh $(r=0.345)(p<0.05)$, pengeluaran total $(r=0.300)$ $(p<0.05)$, skor pengetahuan gizi $(r=0.322)$ $(p<0.05)$, dan IMT $(r=0.285) \quad(p<0.05)$ dengan kadar kolesterol total. Pendidikan contoh $(r=0.348) \quad(p<0.05)$, skor pengetahuan gizi $(r=0.353) \quad(p<0.05)$ berhubungan nyata dengan kadar kolesterol LDL, dan IMT berhubungan nyata $\quad(r=0.365) \quad(p<0.05) \quad$ dengan kadar trigliserida.

\section{DAFTAR PUSTAKA}

[AHA] American Heart Association. 2005. What are healthy levels of cholesterol?. http://www.americanheart.org/present er.jhtml?identifier=183. [21 April 2005].

Almatsier S. 2004. Penuntun Diet Edisi Baru. Gramedia Pustaka Utama, Jakarta.

Alwi I. 1996. Peran triad lipid pada penyakit jantung koroner. Medika, 12,963-970.

Berg A. 1986. Peranan Gizi dalam Pembangunan Nasional. Rajawali, Jakarta.

Bray GA. 1991. Obesitas (Handali S, penerjemah). Dalam Andrianto P (Ed.), Prevention of Coronary Heart Desease Practical Management of The Risk Factors. (hlm: 75-77). EGC, Jakarta.

Hardinsyah, Suhardjo. 1987. Ekonomi Gizi. Jurusan Gizi Masyarakat dan Sumberdaya Keluarga, Fakultas Pertanian, IPB, Bogor.

Hiddin A. 1998. Gambaran Karakteristik dan Status Gizi Pasien Penyakit Jantung Koroner di Instalasi Rawat Inap Rumah Sakit Jantung Harapan Kita. Skripsi Sarjana Fakultas Kesehatan Masyarakat, Universitas Indonesia, Depok.

Kertohoesodo S. 1987. Pengantar Kardiologi. UI Press, Jakarta.

Krisnatuti D, Yenrina R. 1999. Perencanaan Menu Bagi Penderita Penyakit Jantung Koroner. Trubus Agriwidya, Jakarta.

Martianto D \& Ariani M. 2004. Analisis Perubahan Konsumsi dan Pola Konsumsi Pangan Masyarakat dalam Dekade Terakhir. Dalam Soekirman dkk. (Eds.), Ketahanan Pangan dan Gizi di Era Otonomi Daerah dan Globalisasi. Prosiding Widyakarya Nasional Pangan dan Gizi VIII (hlm. 185-190), 17-19 Mei. LIPI, Jakarta.

Riyadi H. 2001. Prinsip dan Petunjuk Penilaian Status Gizi. Fakultas Pertanian, Institut Pertanian Bogor, Bogor. 
Soekirman. 1991. Dampak Pembangunan Terhadap Keadaan Gizi Masyarakat. Pidato Penerimaan Jabatan Guru Besar Luar Biasa Ilmu Gizi di IPB, Bogor.

Suhardjo. 1989. Perencanaan Pangan dan Gizi. Pusat Antar Universitas Pangan dan Gizi, $\mathrm{IPB}$, Bogor.

Sukarni MC. 1989. Kesehatan Keluarga dan Lingkungan. Pusat Antar Universitas. Pangan dan Gizi, IPB, Bogor.

Sulastri D, Ningsih SR, Purwantyastuti. 2005. Pola makan dan profil lipid laki-laki etnik Minangkabau. Medika, 31,160-165.
Sumartono RW, Aryastami NK. 1999. Penyakit jantung dan pembuluh darah pada usia 55 tahun menurut survai kesehatan rumah tangga 1992. Jurnal Cermin Dunia Kedokteran, 5,11-12.

Wiyono S, Bantas K, Hatma RDj, Soekirman SW. 2004. Hubungan antara rasio lingkar pinggang-pinggul dengan kadar kolesterol pada orang dewasa di Kota Surakarta. Jurnal Cermin Dunia Kedokteran, 143,44-48.

Yuniarti SI. 2000. Epidemiologi penyakit jantung koroner. Medika, 5,307-312. 